\title{
SOME LEGAL PROBLEMS IN STATE PERSONAL INCOME TAXATION
}

EDWIN KESSLER, JR.

The publication of income-tax returns has lately called forth considerable polemic literature directed against the very levying of such taxes; a recent amendment to the Florida Constitution prohibits their imposition in that State. The advisability of taxing income as such is not, however, my present thesis, nor do I propose to discuss here the question of privacy versus publicity of returns. I shall limit myself to the consideration of a number of legal problems which inevitably arise when the several states undertake the taxation of personal incomes. Most, if not all, of these problems have an economic aspect and the decisions of the courts will be largely controlled by the economic philosophy of the judges. It follows that the lawyer who would debate these questions must have some appreciation of the economic principles involved, but in this article I shall presuppose, rather than attempt to supply, the requisite background. ${ }^{1}$

\section{The Constitutionality of Progressive Income Taxes}

Whether income taxes should differentiate between "earned" and so-called "unearned" income or be progressive or both is not my present concern; but the first question I shall consider is whether, if such taxes are enacted into law, they are to be held valid under the usual provisions in the State Constitutions that no person shall be deprived of his life, liberty, or property without due process of law, that no one shall be denied the equal protection of the laws, and that taxes shall be uniform.

The courts have very properly held that these provisions do not require identical treatment of all kinds of persons and property subject to the taxing power, but permit reasonable classification (provided that all members of any particular class are treated alike) and, since that is necessarily involved in any useful classification, discrimination. Taxing "unearned" income at a higher rate than income resulting from the individual efforts of the recipient, exempting the first thousand dollars of one's income, or taxing the second at a higher rate than the first thousand does not seem so obviously unreasonable as to be held unconstitutional in spite of the general presumption of constitutionality. ${ }^{2}$ Yet that conclusion has been reached in several jurisdictions. ${ }^{3}$ It will

'Seligman. Essays in Taxation (I921); Seligman. The Income Tax (1921).

'Sinking Fund Cases (1878) 99 U. S. 700, 718; contra: Hackett. The Constiintionality of the Graduated Income Tax Law (1916) 25 Yale LAW JoURNaL, 427.

'Eliasberg Bros. Mercantile Co. v. Grimes (1920) 204 Ala. 492, 86 So. 56; Opinion of the Justices (1918) 220 Mass. 613, 108 N. E. 570; In re Harkness' Fsiate (1922) 83 Okla. 10\%, 204 Pac. 91r. 
be reached in more if the courts follow the logic of their decisions that progressive inheritance taxes are unconstitutional.4

-No reason would justify a court in upholding a progressive income tax while holding a progressive inheritance tax invalid under such provisions as these. But the converse of this proposition is not equally true. Progressive inheritance taxes may be sustained on grounds which apply not at all to income taxes. In Magoun v. Illinois Trust \& Savings Bank, ${ }^{5}$ the Supreme Court of the United States sustained a graded inheritance tax law of Illinois on the ground that "An inheritance tax is not one on the property but one on the succession. The right to take property by devise or descent is the creature of the law and not a natural right-a privilege, and therefore the authority which confers it may impose conditions upon it." The principle that there can be but slight limitations to the regulatory power of the states over such subjects as they may absolutely prohibit obviously has no application to incometaxes.

The Supreme Court of Alabama held a progressive income-tax unconstitutional on the ground that it was a discriminatory property tax. ${ }^{6}$ It is generally assumed that a progressive property tax would be unconstitutional under the Federal Constitution. Assuming that a state, progressive, personal income-tax had been sustained by the state courts, the argument that taxes on income are in reality taxes on the source of that income would be the most serious obstacle in the way when it came to run the gauntlet of the United States Supreme Court. The Supreme Court has shown that it is no slave to logic and, in these days of sociological jurisprudence, many may consider involved formalistic reasoning useless. Yet that Court, not unlike courts of lesser rank, is desirous of disposing of new problems so as to do violence to as few of the general principles on which its prior decisions are based as need be, while, at the same time, doing justice to the new facts presented in the issue. Let us, then, turn to an examination of the cases to determine where lies the preponderance of legal analogy, the answer pointed out by the precedents.

In the famous Pollock cases, ${ }^{7}$ which led directly to the adoption of the

'State v. Gorman (1889) 40 Minn. 232, 4I N. W. 948; State v. Ferris (1895) 53 Ohio St. 314, 4I N. E. 579; State v. Szertaler (1878) 143 Mo. 287, 45 So. 245: "The classification on the basis of amount is artificial, without rhyme or reason."

"( 1898 ) 170 U. S. 283, 18 Sup. Ct. 594; Mager v. Grima (I850, U. S.) 8 How. 490; Matter of Estate of Swift (1893) 137 N. Y. 77, 32 N. E. I096; see Maxwell v. Bugbee (I919) 250 U. S. 525, 54I, 40 Sup. Ct. 2, 7: "The tax is not upon the property but upon the privilege of succession which the state may grant or withhold." Contra: - Nunnemacher v. State (1906) 129 Wis. 190, 108 N. W. 627, on the ground that the right to transmit or succeed to property could not be abrogated in this day and age.

- Supra note 3 .

'Pollock v. Farmers' Loan \& Trust Co. (1895) I57 U. S. 429, I5 Sup. Ct. 673; 158 U. S. 6or, 15 Sup. Ct. 912; Powell, Stock Dividends, Direct Taxes and the Sixteenth Amendment (1920) 20 CoL. L. REv. 536. 
Sixteenth Amendment, a tax on the income from real and personal property was said to be equivalent to and as "direct" as a tax on the land or personalty and was held to violate the requirement of the Federal Constitution that "direct taxes shall be apportioned among the several states according to their respective numbers." The Sixteenth Amendment provides that "Congress shall have power to lay and collect taxes on incomes, from whatever source derived, without apportionment among the several States," but says nothing as to the "directness" of an income tax, whether it is or is not a tax on the source of the income. ${ }^{9}$ The language, if not the holding, of the Pollock cases lends strength to the argument that progressive income taxes are unconstitutional, being discriminatory property taxes.

Those who advocate this position claim to find further support in the long line of decisions that a state tax on the gross receipts of a corporation engaged in interstate commerce is unconstitutional. ${ }^{10}$ A complete answer to this claim is that net income from interstate commerce may be taxed, provided only that it is not discriminated against as such. ${ }^{11}$ All the state income taxes are levied on net income.

But there is a more fundamental reason why the interstate commerce tax-decisions are of no significance here. The Federal Constitution gives Congress the "Power to regulate Commerce ... . among the several States"12 and this has been held to prohibit state regulation of interstate commerce ${ }^{13}$ but there is strictly no inhibition on the states to tax interstate commerce and taxation falling short of regulation is not unconstitutional. ${ }^{14}$ These decisions, then, depend solely on the effect of

'U. S. Const. Art. I, sec. 2, cl. 3; ibid. Art. I, sec. 9, cl. 4.

- Peck \& Co. v. Lozere (rgi8) 247 U. S. 165, 38 Sup. Ct. 432 : "The Sixteenth Amendment does not extend the taxing power to new or excepted subjects but merely removes all -occasion which otherwise might exist for an apportionment among the states of taxes laid on income, whether it be derived from one source or another."

${ }^{10}$ Phila. \& So. S. S. Co. v. Penn. (1887) 122 U. S. 326,7 Sup. Ct. III8; Galveston, $H$. \& S. A. Ry. v. Texas (1908) 210 U. S. 217, 28 Sup. Ct. 638. See Irt. Paper Co. v. Mass. (I918) 246 U. S. I35, 38 Sup. Ct. 292.

I U. S. Glue Co. v. Oak Creek (1918) 247 U. S. 32I, 38 Sup. Ct. 499 ; Shaffer v. Carter (1920) 252 U. S. 37, 40 Sup. Ct. 22r.

${ }^{12}$ U. S. Const. Art. I, sec. 8, cl. 3.

"Galveston, etc. $R y$. v. Texas, supra, note Io at p. 227 : "If it (the tax) bears upon commerce among the states so directly as to amount to a regulation in a relatively immediate way, it will not be saved by name or form." Phila. $\mathcal{E}$ So. S. S. Co. v. Penr., supra note II, at p. 328: "The corporate franchises, the property, the business, the income of corporations created by a state may undoubtedly be taxed by the state; but in imposing such taxes care should be taken not to interfere with or hamper, directly or by indirection, interstate or foreign commerce or any other matter exclusively within the jurisdiction of the Federal Government."

"This rule is well stated by Prof. T. R. Powell in State Income Taxes and the Commerce Clause (1922) 3I Yale LaW JournaL, 799: "Law, like politics, makes strange bedfellows. Among the queerest of such companions are the doctrine that the states cannot tax interstate commerce and the fact that they can. As 
the tax and not on the subject of the tax. Obviously, many statutes might be unconstitutional regulations of interstate commerce without being taxes at all.

For the same reason the argument based on the Federal instrumentality tax-decisions must be dismissed; for any law which hampers the United States in the exercise of its governmental functions will be unconstitutional irrespective of the subject-matter of the tax. ${ }^{15} \mathrm{~A}$ property tax may well be a burden on the person who owns the property but no court would hold it a personal tax for that reason. Yet we cannot lightly pass over the reasoning in the recent case of Gillespie $v$. Oklahoma. ${ }^{16}$ In Choctaw, Oklahoma \& Gulf R.R. v. Harrison ${ }^{17}$ the Supreme Court had ruled that a lessee of restricted Indian lands could not be taxed by a state on his gross receipts from the use of such property where the tax was in addition to general ad valorem taxes. Later, in Howard v. Gipsy Oil Co., ${ }^{18}$ a gross production tax was held bad though imposed on such lessee in lieu of the ordinary property taxes. In the Gillespie case a tax on the net income derived from such lands was held invalid. The Court said:19 "The same considerations that invalidate a tax upon the leases ${ }^{20}$ invalidate a tax upon the profit of the leases, and, stopping short of theoretical possibilities, a tax upon such profits is a direct hamper upon the effort of the United States to make the best terms that it can for its wards." That was sufficient to decide the case but, not content with this, the Court indulged in the following dictum:"1 "A tax upon the leases is a tax upon the power to make them, and could be used to destroy the power to make them. The step from this to the invalidity of the tax upon income from the leases is not long. In cases where the principal is absolutely immune from interference an inquiry is allowed into the source from which such income is derived and if a part of it comes from such a source the tax is 'pro tanto' void," citing the Pollock cases. It would be difficult to explain away this language; the Supreme Court has manifested a willingness to ignore it and to act on contrary premises.

might be anticipated, the doctrine and the fact do not dwell together in perfect amity. ... The truth is that there is a wrong way and a right way for the states to tax interstate commerce." Were the rule otherwise it would amount to giving a bounty to interstate commerce.

${ }^{15}$ Salaries of federal employees are exempt from state taxation. Evans v. Gore (rgig) 253 U. S. 245. 40 Sup. Ct. 550; Dobbins v. Comm's. of Erie County ( 1842 , U. S.) I6 Pet. 435 ; and so is income from obligations of the United States which have been made tax-exempt by Act of Congress. Lantz $v$. Hanna (1922) III Kans. 46I, 207 Pac. 767; cf. Farmers' Bank v. Minn. (I914) 232 U. S. 5 I6. 34 Sup. Ct. 354

${ }^{10}$ (1922) 257 U. S. 501, 42 Sup. Ct. 171.

${ }^{17}$ ( I914) 235 U. S. 292, 35 Sup. Ct. 27.

${ }^{28}$ ( I918) 247 U. S. 503, 38 Sup. Ct. 426.

10 Supra note 16, at p. 506, 42 Sup. Ct. 172.

${ }^{20}$ Indian Oil Co. v. Oklahoma (I916) 240 U. S. 522, 36 Sup. Ct. 453.

"Supri note I5, at p. 505, 42 Sup. Ct. 172. 
The Constitution of the United States prohibits Congress from levying any tax, impost, or duty on exports. ${ }^{22}$ Yet in Peck \& Co. v. Lowe ${ }^{23}$ the Court sustained the application of the Federal Income Tax to the net income of an export-house. The ground of the decision was that the tax, being laid generally on net income, not on income from exportation because of its source or in the way of discrimination, and affecting only the net receipts from exportation after all expenses were paid and losses adjusted and the recipient was free to use the income as he chose, only indirectly and remotely affected exportation and could not be said to be a tax thereon. The case, of necessity, is a square holding that a tax on the net income from exportation is not a tax on exportation.

The decision in Brushaber v. Union Pac. R.R., ${ }^{24}$ upholding the Federal Progressive Income-Tax, has no significance here. Congressional action is not limited by an "equal protection of the laws" clause, as is state action, and the "due process" clause of the Fifth Amendment has been held not to be a limitation on the taxing power conferred upon Congress by Article I, sec. 8 of the Constitution. ${ }^{25}$

The result of this discussion seems to be that the United States Supreme Court may logically hold valid a state, progressive, personal income-tax though it would not do as much for a progressive property tax. But will the income-taxes be sustained? In so far as they may interfere with any federal instrumentality, certainly not; but apart from this it seems well-nigh certain that they will be upheld. That result may be reached by regarding them as personal taxes, measured by the income of the recipient; by regarding income as a new thing, separate and distinct from the source from which it is derived; by holding that even a property tax may be progressive if the form of the tax is such as to make allowance for the productiveness of the property and the personal condition of the owner; or, finally, by disregarding formalistic reasoning and relying on grounds of economic expediency. Obviously the last method has all the advantages of simplicity and the Supreme Court has manifested a willingness to follow this path of least resistance.

In Knowlton v. Moore ${ }^{26}$ a federal progressive inheritance tax was sustained. That case amounted to considerably more than a reaffirmance of the decision in Magoun $v$. Illinois Trust \& Sazings Bank. ${ }^{27}$ There is no basis for contending that the Federal Government could abolish the right, existing under state laws, to inherit or take property under the validly executed will of a competent testator, and the tax could not be sustained as a condition annexed to the privilege of succession.

$=$ U. S. Const. Art. I, sec. 9. cl. 5.

$=$ (InI8) 247 U. S. 165, 38 Sup. Ct. 432.

34 (1916) 240 U. S. I, 36 Sup. Ct. 236.

${ }^{25}$ Ibid. 24 and cases cited, 36 Sup. Ct. at p. 244

* (ro00) 178 U. S. 4I, 20 Sup. Ct. 747. Brewer, J., dissented.

"Silpra note 5. 
The Court said :28 "Taxes imposed with reference to the ability of the person upon whom the burden is placed to bear the same have been levied from the foundation of government. So, also, some authoritative thinkers, and a number of economic writers, contend that a progressive tax is more just and equal than a proportional one. In the absence of constitutional limitation, the question whether it is or is not is legislative and not judicial."29 This language is sweeping and unqualified but it goes much further than the actual decision demanded. The court was not considering a tax on property but an excise on the transmission of a decedent's estate; the former falls due every year; the latter, once in a life-time. The dictum is of value, however, to show the attitude of the court towards progression in taxation generally.

In Shaffer v. Carter ${ }^{30}$ it was argued that since a state cannot tax property permanently situated in another state it cannot tax the income from such property, though it be earned by a resident. Mr. Justice Pitney replied: "This argument, upon analysis, resolves itself into a mere question of definitions, and has no legitimate bearing upon any question raised under the Federal Constitution. For where the question is whether a state taxing law contravenes rights secured by that instrument, the decision must depend not upon any mere question of form, construction or definition, but upon the practical operation and effect of the tax imposed." The Court declined to characterize the tax as one on the person or on the property.

(To be continued)

Supra note 26 , at p. I09, 20 Sup. Ct. at p. 774.

- This was the basis of the Wisconsin decision sustaining the state, personal, progressive income-tax. Income Tax Cases (Igr2) 148 Wis. 456,134 N. W. 673 ; State v. Johrson (I9I9) I70 Wis. 218 , I75 N. W. 589.

- (1920) 252 U. S. 37, 40 Sup. Ct. 221. 